\title{
THE ENFORCEMENT OF THE WHIPPING SENTENCE AS PART OF THE JINAYAH LAW IN ACEH PROVINCE, INDONESIA
}

\author{
Mohd. Din* \\ M. Nur.**
}

\begin{abstract}
The purpose of this article is to determine the factors that hinder the implementation of the whipping sentence under Aceh's Jinayah Qanun and the efforts made in overcoming these obstacles. The method used is empirical juridical, using data from the field as the main source. This is done by collecting data from several regions in Aceh, followed by interviews with the prosecutors as the executor in Sharia Court for the Jinayah case. The results show that the execution is the final stage of the judicial process and is expected to achieve the objectives of justice, but there are some cases of jinayah which are not fully executed due to some obstacles that arose. The main obstacles are lack of funding, human resources, and coordination among subsystems in the jinayah justice. The lack of funding will result in delays in implementing whipping punishment so that when it is carried out, it is difficult to bring the convicted person into prison. The efforts made to overcome this problem are by carrying out whipping with minimum funding, developing human resources, and coordinating with the local government to support this execution process.
\end{abstract}

Keywords: execution of whipping, jinayah law, Aceh province, criminal law in Indonesia.

* Faculty of Law, Universitas Syiah Kuala (USK). Email: m_din@unsyiah.ac.id.

** Faculty of Law, Universitas Syiah Kuala (USK). Email: nur.rasyid99@gmail.com. 


\title{
PENGUATKUASAAN HUKUMAN ROTAN SEBAGAI UNDANG-UNDANG JENAYAH DI PROVINSI ACEH, INDONESIA
}

\begin{abstract}
ABSTRAK
Makalah ini bertujuan untuk menentukan faktor-faktor yang menghalang pelaksanaan hukuman sebat di bawah Jinayah Qanun Aceh dan usaha yang dilakukan dalam mengatasi rintangan ini. Kaedah yang digunakan adalah empirikal dimana data dari lapangan di kaji sebagai sumber utama. Ini dilakukan dengan mengumpulkan data dari beberapa daerah di Aceh, diikuti dengan wawancara dengan Jaksa sebagai pelaksana di Mahkamah Syariah untuk kes-kes jenayah. Hasilnya menunjukkan bahawa pelaksanaannya adalah tahap akhir dari proses kehakiman dan diharapkan dapat mencapai tujuan keadilan, tetapi ada beberapa kes jenayah yang tidak dapat dilaksanakan sepenuhnya kerana beberapa halangan yang timbul. Halangan utama adalah kekurangan dana, sumber daya manusia, dan koordinasi antara subsistem dalam keadilan jinayah. Kekurangan dana akan mengakibatkan kelewatan dalam melaksanakan hukuman sebat sehingga Ketika ia dijalankan, sukar untuk membawa pesalah ke penjara. Usaha yang dilakukan untuk mengatasi masalah ini adalah dengan melakukan sebat dengan dana minimum, mengembangkan sumber daya manusia, dan bekerjasama dengan pemerintah daerah untuk mendukung proses pelaksanaan ini.
\end{abstract}

Kata kunci: pelaksanaan hukuman sebat, hukum jinayah, provinsi Aceh, hukum pidana di Indonesia.

\section{INTRODUCTION}

The commitment to fully implement the Shari'ah in Aceh can be seen in the enactment of several regional regulations in the form of a statute known as the Qanun. Ever since the early independence of Indonesia, the Shari'ah has been part of a way of life for the Acehnese people. This implementation is initially marked by the promulgation of Act No. 44 of 1999 concerning Aceh's Special Autonomy, along with Regional Regulation No. 5 of 2000 concerning the Implementation of the Shari'ah in Aceh. ${ }^{1}$

1 Mohd. Din. “Aceh's Jinayah Justice System". Mondial 13, no. 22 (2010): 93-105. 
Whipping is a form of punishment under the Shari'ah that is enforced in Aceh and has often been carried out in all regencies in Aceh. For example, eighteen people were convicted for khalwat (seclusion), drinking khamar (intoxicants) and maisir (gambling) were sentenced to be whipped in Rukoh Village, Syiah Kuala District, Banda Aceh $^{2}$. The whipping was carried out in accordance with the application of the special autonomy granted to the Province of Aceh by the enactment of the Shari'ah law through Act Number 44 of 1999 concerning Aceh's Privileges and Act Number 18 of 2000 concerning Special Autonomy for Aceh which was then replaced by Act Number 11 of 2006 concerning the Government of Aceh. Based on this law, several Qanun related to drinking khamar, maisir, and khalwat have been established as crimes under the said laws. In fact, most Muslims in the region were required to abide by the Shari'ah before the implementation of this Act. Currently, this Qanun has been merged into Qanun number 6 of 2014 concerning Jinayah, which was effective from October $28^{\text {th }}, 2015 .^{3}$

There are some obstacles in the execution of the whipping, among others, are in connection with the criticism that whipping is considered against human rights, and the community's impression that whipping has not been properly carried out due to the convicts escaping the sentence. This is certainly a problem in law enforcement of Jinayah in Aceh, which would later become a model for some regions in Indonesia. $^{4}$

The philosophy of punishment in the execution of whipping is not fully understood yet by some groups, including the people of Aceh. There is an excessive fear of the enforcement of the Shari'ah law, where there is an assumption that the enforcement of Shari'ah law will affect development in Aceh. There is an assumption that the provisions in the Qanun Jinayah will influence the achievement in Aceh, such a magnified fear is due to people's limited understanding of the true

2 "Executioner's Actions According to The Rules," Daily Serambi Indonesia Newspaper, accessed March 1, 2016, https://aceh.tribunnews.com/2016/03/03/tindakan-algojo-sesuai-aturan.

3 Qanun Nanggroe Aceh Darussalam Province No. 6 Year 2014 Qanun Aceh on Jinayat Law (2014).

4 Mohd. Din, "Authority of the Syariyah Court in the Criminal Justice System" in Training Integrasi bagi Aparatur Hukum Aceh (Speech, Banda Aceh, November, 2017). 
nature of the law. This is exacerbated by the implementation of whipping which is not in accordance with the stipulated provisions and is also related to other statutory provisions that must be considered in law enforcement in general. Cases of violations also occur in the implementation of whipping for example where more whipping was applied by the executor over a convinced perpetrator. Also, in the socialization of technical aspect of Qanun Jinayat on 24 to 27 June 2017 at Middle Aceh (Aceh Tengah District) revealed that no all district/city in Aceh province have internal crime investigator for officials (Penyidik Pegawai Negeri Sipil) for enforcing Qanun Jinayah, which hinders the perpetrators from being prosecuted.

Whipping implementation is based on Governor Regulation Number 10 of 2005 concerning the implementation of whipping Sentence. Now the provisions regarding the implementation of whipping are contained in the Jinayah Qanun, namely Qanun Number 7 of 2013. There are several problems in the execution of the whipping sentence. ${ }^{5}$ Based on this background, this article will cover factors that hinder the execution of whipping sentence and what efforts are required to overcome these obstacles.

The purpose of the current study is to examine the obstacles in the execution of whipping and the efforts made to overcome them by using empirical legal methods. This method looks at and examines the application of the law in the field regarding the execution of whipping. By examining the principles of law in its enforcement, we will understand the problems encountered in the enforcement of the Jinayah Qanun in Aceh.

Data collection was carried out in two stages, namely library research and field research. Library Research (library research) was done to obtain secondary data in the form of legal materials, namely primary, secondary, and tertiary legal materials. Primary legal materials consist of related laws and regulations. Secondary legal materials consist of related literature which are in line with primary legal materials including textbooks, article journals, and previous studies. Tertiary legal materials consist of materials that provide explanations to secondary legal materials such as relevant encyclopedias, bibliographies, and dictionaries. Field research was

5 Report, the Integration Training Activity for Law Officers in Aceh on 7 to 9 November 2017 in Banda Aceh, held by the Aceh Sharia Service. 
carried out through in-depth interviews with respondents and informants. The research sites were Aceh Besar District, Aceh Barat District, Jeumpa District, and Pidie District. The population for this study is law enforcement officers involved in the Jinayah judicial system, ranging from investigators, public prosecutors, judges, and Wilayatul Hisbah (Islamic religious police) ${ }^{6}$ as executors of the whipping execution. Data collected from the results of field research and library research were analyzed by using a qualitative method with a descriptive approach.

\section{DISCUSSION}

\section{Inhibiting factors for the implementation of whipping sentence}

Whipping as one of the forms of sentence implementation in Aceh is legally mentioned in several Qanuns in Aceh and it is also mentioned in Act Number 11 of 2006 concerning Governance of Aceh, a province granted special autonomy to implement Shari'ah law in Indonesia. Some provisions in Law No. 11 of 2016 concerning the permissible punishment of lashing and execution by the Court of Syariyah can be explained as implied in Article 241 paragraph (2) which reads "Qanun can contain the threat of imprisonment for a maximum of 6 (six) months and/or a maximum fine of Rp. 50,000,000.00 (fifty million rupiahs". While paragraph (4) reads: "Qanun concerning jinayah (criminal law) is excluded from the provisions of paragraph (1), paragraph (2), and paragraph (3)." This means the content of qanun that does not regulate Islamic sharia, the sanction is the same as the Regulation, namely "criminal confinement for a maximum of 6 (six) months and/or a maximum fine of Rp. 50,000,000.00 (fifty million rupiahs". However, the qanun concerning Islamic law is excluded from this provision.

If observed provision 241, Qanun can be divided in two: general and sharia Qanun. Therefore, in Sharia qanun, it is permissible to apply criminal threats outside the provisions contained in the legislation in Indonesia in general, one of which is the punishment of whipping. There have been many studies into the punishment of this whip, both

6 Wilayatul Hisbah is an institution involved in the Jinayah Judiciary in Aceh. In general, its function is to supervise the implementation of Islamic Shari'a in Aceh Province. 
the pros and cons. But in terms of criminal law policy where criminal or punishment is one of its central problems, this type of criminal lashing is part of the criminal type in Islam can enrich the alternative sanctions to find the ideal form of criminal in tackling crime. It is increasingly based on the Development of Criminal Law with criminalization as one of its central problems, must communion the values that live in the community, in this case, the Acehnese society that highly upholds the values of Islam. Even criminalization in the perspective of the Indonesian nation puts Pancasila as the source of all legal sources. criminalize in the perspective of Pancasila among others must be oriented to the principle of human recognition as a creature of God. The form of criminalizing should not be contrary to any religious beliefs embraced by the people of Indonesia. criminalize should be directed towards the awareness of the faith of the convicted to repent and become a man of faith and obedience. Hence, criminalization should serve to mentally foster the person who is convicted and transform the person into a religious human being.

Furthermore, Article 128 paragraph (3) of Law No. 11 of 2006 concerning the Government of Aceh, among others, states that the Sharia Court is authorized to examine, adjudicate, decide, and resolve jinayah cases based on Islamic sharia. This provision is the delegation of judicial authority to the region and strengthens the function of the Sharia Court which had previously been approved through Presidential Decree No. 11 of 2003. Today there are several Qanun about Islamic sharia that has been established as the basis for the work of the Jinayah Justice System.

For this implementation, several Jinayah Qanun (containing criminal provisions $)^{7}$ have been enacted and the judicial process has been carried out in the criminal justice system. This system is different from the criminal justice sub-system in general where it has a special institution to implement Shari'ah law, known as Wilayatul Hisbah, one of which duties is to carry out whipping executions.

The term of Jinayah Justice System is used only to replace the term Criminal Justice System. ${ }^{8}$ The Criminal Justice System is a

7 Mohd. Din, Stimulation of Development of National Criminal Law, From Aceh to Indonesia. (Bandung: UNPAD, 2009), 9.

8 Mohd. Din. “Aceh's Jinayah Justice System". Mondial 13, no. 22 (2010): 93-105. 
system of the process of criminal justice, which consists of police as investigators, prosecutors as public prosecutors, courts in the justice side, and prisoner institutions that function as rehabilitation centers. These institutions work together in an integrated system as an effort to achieve a common goal, namely to tackle crimes so that it is within the acceptable tolerance limits of society. ${ }^{9}$ The task of the criminal justice system is indeed very broad because it includes:

1. to prevent people from becoming victims of crime,

2. to resolve crimes that occur so that people are satisfied that justice has been upheld and the guilty are convicted, and

3. to prevent those who have committed a crime from repeating his actions ${ }^{10}$.

The whip criminal implementation as expected is an effort in law enforcement carried out through the judiciary. The role of the judiciary in a modern state like Indonesia is important because it would be impossible for the life of the state to run properly and fairly without any institution that functions to uphold the law and adjudicate disputes between the people and the government or between the people and other members of the community. Criminal punishment is essential as a means of realizing justice. The justice sought here is in the context of preventive actions, bringing goodness, seeking justification, and also relating to forward-looking views. ${ }^{11}$

Enforcement of law and justice is one function of the sovereignty of a state. David Storey emphasized the role and function of the state, namely:

1. Regulating the country's economy.

2. Providing public needs and interests, especially health and transportation.

9 Norval Morris, Criminal Justice in Asia, Quest for an Integrated Approach, (Newyork : UNAFEI, 1982), 5.

10 Mardjono Reksodiputro, Criminology and the Criminal Justice System. Second Collection of Book Essays (Jakarta: Center for Justice and Legal Service, 1994). 140.

11 Suhariyono. "Formulation of Criminal Sanctions in the Formation of Legislation," Perspective 17, no. 1 (2012): 20-21. 
3. Providing legal instruments and uphold justice for its people.

4. Defending and protecting the territory of the state and the security of its people from any outside threats.

There is no civilized nation without an independent judiciary because one of the pillars supporting the upholding of the country's sovereignty is the existence of a sovereign court. The court entity is an institution tasked with enlightening and providing direction for the journey of the nation's civilization. ${ }^{12}$

The Qanun Jinayah is created to be upheld, thus the formulation of offense and the determination of criminal penalties in the Qanun must take into account how it is enforced. In this connection, Sudarto reminded the Indonesian people of the following:

The use of criminal law must accommodate national development goals, namely to create a just and prosperous society that is material and spiritually based on Pancasila; in connection with that, the (use of) criminal law aims to tackle crime and also conduct granting of the actions of the tackling itself, for the sake of the welfare and protection of the community;

1. Acts which are endeavored to be prevented or overcome by criminal law must constitute "desirable acts", i.e., acts that cause harm (material and / or spiritual) to the community members;

2. The use of criminal law must take into account the principle of "costs and results" (cost and benefit principle);

3. The use of criminal law must also pay attention to the work capacity or capacity of law enforcement agencies, that is, the punishment must not be excessive. ${ }^{13}$

${ }^{12}$ David Storey, a Territory The Claiming of Space (United State: Prentice Hall, 2001), 39.

${ }^{13}$ Sudarto, Criminal Law and Law, (Bandung: Alumni, 1986), 35-41. 
In its implementation, the provisions of the Qanun jinayah which have not been executed properly include the punishment of whipping. The following table illustrates this claim:

Table 1: Examples of whipping punishments not being properly executed.

\begin{tabular}{|c|c|c|c|}
\hline No. & $\begin{array}{l}\text { Decision Number / } \\
\text { Register }\end{array}$ & Execution & $\begin{array}{l}\text { Jurisdictional } \\
\text { regency }\end{array}$ \\
\hline 1 & $\begin{array}{l}\text { 05/2018/M.S-MBO; } \\
17 \text { April 2018. Name } \\
\text { Toroziduhu Zebua } \\
\text { bin Taliarozebua } \\
\text { (50 times Whipping) }\end{array}$ & $\begin{array}{l}50 \text { times Whipping } \\
11 \text { Mei } 2018\end{array}$ & Nagan Raya \\
\hline 2 & $\begin{array}{l}\text { 07/JN/2018/M.S- } \\
\text { MBO; } 6 \text { April } 2018 . \\
\text { Name Rahmat Efendi } \\
\text { bin Alm Ishak } \\
\qquad(24 \text { times } \\
\text { Whipping) }\end{array}$ & $\begin{array}{l}24 \text { times Whipping } \\
6 \text { April } 2018\end{array}$ & \\
\hline 3 & $\begin{array}{l}\text { 09/JN/2017/M.S- } \\
\text { Aceh; 21 Desember } \\
2017 . \quad \text { Name } \\
\text { Sulaiman Ismail bin } \\
\text { Ismail } \\
\text { (100 times Whipping } \\
\text { prison sentence } 2 \\
\text { years) }\end{array}$ & $\begin{array}{l}100 \text { times Whipping } \\
\text { Prison sentence } 2 \\
\text { years } \\
6 \text { April } 2018\end{array}$ & \\
\hline 4 & $\begin{array}{l}\text { PDM- } \\
\text { 61/SGL/06/2017; } \\
\text { Name Angga } \\
\text { Wirayuda Bin } \\
\text { Burhanuddin. } \\
\text { (100 times Whipping }\end{array}$ & $\begin{array}{l}100 \text { times Whipping } \\
\text { reduced prison time, } \\
12 \text { Juli } 2017\end{array}$ & Sigli \\
\hline
\end{tabular}




\begin{tabular}{|c|c|c|c|}
\hline & reduced prison time) & & \\
\hline 5 & $\begin{array}{l}\text { 03/JN/2017/MS- } \\
\text { MBO ;16 Maret } \\
\text { 2017. Name Maisir } \\
\text { Bin T. Mahmuddin. } \\
\text { (15 times Whipping) }\end{array}$ & $\begin{array}{l}11 \text { times Whipping } \\
\text { reduced prison } \\
\text { term, detained } 85 \\
\text { days based on the } \\
\text { provisions of the } \\
\text { Sharia Court } \\
30 \text { November } 2017\end{array}$ & Melaboh \\
\hline 6 & $\begin{array}{l}\text { 15/JN/2017/MS- } \\
\text { MBO;28 September } \\
2017 \text { Name Januar } \\
\text { Hariyono Bin } \\
\text { Alm.Amran. } \\
\text { (30 times Whipping) }\end{array}$ & $\begin{array}{l}26 \text { times Whipping } \\
\text {, reduced prison time } \\
30 \text { November } 2017 \text {. }\end{array}$ & \\
\hline 7 & $\begin{array}{l}\text { 16/JN/2016/MS- } \\
\text { MBO; 28 September } \\
\text { 2017. Name Zulaidi } \\
\text { Bin Ali Basyah. } \\
\text { (100 times } \\
\text { Whipping) }\end{array}$ & $\begin{array}{l}100 \text { times Whipping } \\
30 \text { November } 2017\end{array}$ & \\
\hline 8 & $\begin{array}{l}\text { 13/JN/2016/MS- } \\
\text { MBO; 9 Agustus } \\
\text { 2016. Name Mak'un } \\
\text { Bin Alm. M. Yatim. } \\
\text { (8 times Whipping) }\end{array}$ & $\begin{array}{l}7 \text { times Whipping } \\
\text { reduced prison time } \\
30 \text { Novemebr } 2017 \text {. }\end{array}$ & \\
\hline 9 & $\begin{array}{l}\text { 13/JN/2016/MS- } \\
\text { MBO; 9 Agustus } \\
\text { 2016. Name Mustafa } \\
\text { bin Abdul Rahman. } \\
\text { (8 times Whipping) }\end{array}$ & $\begin{array}{l}7 \text { times Whipping } \\
30 \text { November } 2017 .\end{array}$ & \\
\hline
\end{tabular}




\begin{tabular}{|c|c|c|}
\hline 10 & $\begin{array}{l}\text { 13/JN/2016/MS- } \\
\text { MBO; 9 Agustus } \\
\text { 2016. Name Mirwan } \\
\text { Noet Bin Alm. Nawi. } \\
\text { (8 times Whipping) }\end{array}$ & $\begin{array}{l}7 \text { times Whipping } \\
\text { reduced prison time } \\
30 \text { November } 2017 \text {. }\end{array}$ \\
\hline 11 & $\begin{array}{l}\text { 13/JN/MS-MBO; } 9 \\
\text { Agustus 2016. Name } \\
\text { T. Zulriflan Tris Bin } \\
\text { Alm.Muslim. } \\
\text { (8 times Whipping) }\end{array}$ & $\begin{array}{l}6 \text { times Whipping } \\
\text { reduced prison time } \\
30 \text { September } 2017 .\end{array}$ \\
\hline 12 & $\begin{array}{l}\text { 13/JN/MS-MBO; } 9 \\
\text { Agustus 2016. Name } \\
\text { Amin Jalaludin Bin } \\
\text { Alm. Nyak Bintang. } \\
\text { (8 times Whipping) }\end{array}$ & $\begin{array}{l}7 \text { times Whipping } \\
\text { reduced prison time } \\
30 \text { November } 2017 .\end{array}$ \\
\hline 13 & $\begin{array}{l}\text { 10/JN/MS-MBO; } 22 \\
\text { Juni } 2016 . \\
\text { Name Syamsuddin } \\
\text { Bin Alm. Rusli } \\
\text { Hamid. } \\
\text { (8 times Whipping) }\end{array}$ & $\begin{array}{l}7 \text { times Whipping } \\
\text { reduced prison time } \\
30 \text { November } 2017 .\end{array}$ \\
\hline 14 & $\begin{array}{l}\text { 08/JN/2016/MS- } \\
\text { MBO; 28 April } 2016 . \\
\text { Name Basri Bin } \\
\text { Jalin. } \\
\text { (7 times Whipping) }\end{array}$ & $\begin{array}{l}6 \text { times Whipping } \\
\text { reduced prison time, } \\
30 \text { November } 2017 \text {. }\end{array}$ \\
\hline 15 & $\begin{array}{l}\text { 08/JN/2016/MS- } \\
\text { MBO; 28 April } 2016 . \\
\text { Name Junifizar bin } \\
\text { Puteh. } \\
\text { (7 times Whipping) }\end{array}$ & $\begin{array}{l}6 \quad \text { kali cambuk } \\
\text { reduced prison time } \\
30 \text { November } 2017 .\end{array}$ \\
\hline 16 & $\begin{array}{l}\text { 12/JN/2016/Ms- } \\
\text { MBO; 22 Juni } 2016 . \\
\text { Name }\end{array}$ & $\begin{array}{l}7 \text { times Whipping } \\
\text { reduced prison time }\end{array}$ \\
\hline
\end{tabular}




\begin{tabular}{|c|c|c|}
\hline & $\begin{array}{l}\text { Saputra bin Alm. } \\
\text { Amin. } \\
\text { (8 kali cambuk) }\end{array}$ & 30 November 2017. \\
\hline 17 & $\begin{array}{l}\text { 9/Jn/2017/MS-MBO; } \\
\text { 07 Juni 2017. Name } \\
\text { Agus Rizwan bin } \\
\text { Hasbullah. } \\
\text { (100 times } \\
\text { Whipping) }\end{array}$ & Not executed yet \\
\hline 18 & $\begin{array}{l}\text { 06/JN/2015/MS- } \\
\text { MBO; } 4 \text { Juni } 2015 . \\
\text { Name Misyanto bin } \\
\text { Bustam } \\
\text { (9 times Whipping) }\end{array}$ & Not executed yet \\
\hline 19 & $\begin{array}{l}\text { 12/JN/2015/MS- } \\
\text { MBO; } 04 \text { Juni } 2015 . \\
\text { Name Riswandi } \\
\text { Susanto } \\
\text { Alm.Supardin } \\
\text { Rahmi. } \\
\text { (9 times Whipping) }\end{array}$ & Not executed yet \\
\hline 20 & $\begin{array}{l}\text { 06/JN/2015/MS- } \\
\text { MBO; 10 Juni } 2015 . \\
\text { Name Zainuddin bi } \\
\text { Alm. Tirta. } \\
\text { (Times Whipping) }\end{array}$ & Not executed yet \\
\hline
\end{tabular}

The data above demonstrate that in the study area, except in Meulaboh, the grace period between the decision of the Shari'ah Court and the execution of the whipping sentence was very long, and some were not even executed. This is seen on the date of the verdict with the execution as seen in no. 5 in the verdict 03/JN/2017/MS-MBO; decided on March 16, 2017 and was executed on November 30, 2018). 
There are indeed several factors that influence the enforcement of the law theoretically, including facilities and infrastructure. Likewise, in the study area, the cause of the delay in carrying out whipping is generally due to facilities and infrastructure, namely funding problems. If funds are available, the exclusion is immediately carried out. For example, the Shari'ah Court of Meulaboh, which oversees two districts in handling the Jinayah cases, namely Meulaboh and Nagan Raya ${ }^{14}$, reported that the executions were different in these regions. In Nagan Raya, the execution was immediately carried out shortly after the court's decision as the required funds for the implementation were available, while in Meulaboh the delay could be up to two years. The issue of the implementation of the execution of whips constrained by funds is always a discussion in every meeting, it seems that this has become a public secret, this is revealed based on interviews with respondents.

The Chief of the Syar'iyah Court at Meulaboh explained that, in the settlement of the Jinayah case, his verdict did not only impose whipping, but also imprisonment. ${ }^{15}$ This is different from other regions in which the public often assume that the Shari'ah court is identical to whipping.

Some decisions that impose imprisonment sentences, among others, can be seen in the appeal Decision Number 01 / JN / 2018 / MS. Aceh. The appeal Decision strengthens the Decision Number 025/JN / 2017 / MS.Mbo dated February 7, 2018, of which the ruling are as follows:

1. To declare the Defendant has been legally proven and convicted of committing "Jarimah Sexual Harassment" as stipulated in Article 46 of the Aceh Qanun Number 6 of 2014 concerning Jinayat Law as in the single indictment of the Public Prosecutor;

2. Punishing the Defendant (....) therefore with 'uqubat ta'zir imprisonment for 30 (thirty) months with the

14 The Meulaboh Syar'iyah Court handled jinayah cases originating from two legal areas, namely the jurisdiction of West Aceh Regency and also Nagan Raya Regency. This is because Nagan Raya is a new division and there is no Syar'iyah Court in the jurisdiction.

15 Interview with Chairwoman of Mahkamah Syariyah Meulaboh, March 20, 2018. 
stipulation that the length of time the defendant is detained will be deducted entirely from the Uqubat Ta'zir which was dropped;

3. Order the Defendant to remain in custody;

In this Decision, the Majlis Hakim sentenced him to prison, although the public prosecutor in his lawsuit complied not only with prison sentences but also with whipping or fines. The imprisonment on the one hand is to avoid the arrears of decisions that were not executed because imprisonment is certainly immediately executed after the verdict.

If related to funding in the execution of the whip in the districts of West Aceh and Nagan Raya, it is strongly influenced by the coordination between the Satpol PP (Wilayatul Hisbah) and other subgovernments. Based on the information from the Meulaboh District Attorney, coordination between law enforcement officials and the local government has not been going well. While the whip punishment is carried out by the Wilayatul Hisbah $(\mathrm{WH})$ and all the financing is sourced from the Meulaboh Regency Revenue Budget (APBK), the Government the West Aceh region lacks responsiveness and actively supports the implementation of whipping. For this reason, the State Prosecutor's Office has been anchored through general prosecutors to take an initiative to approach the West Aceh Regency Government for budgeting for the cost of implementing the sentence that is increasingly overdue. There are even cases from 2015 which was only be executed at the end of 2017. ${ }^{16}$ Following this approach, the West Aceh District Government finally provided support to the implementation of whipping. This funding is important because the implementation of whipping involves various parties and requires funding and facilities, so it is highly dependent on funding sources and good coordination between investigators, judges, executors, and the WH as the executor of the whipping sentence.

The parties involved in the execution of whipping are as regulated in Article 252 paragraph (2) of the Aceh Qanun Number 7 of 2013 concerning Jinayah Procedural Laws, namely Prosecutors, Sharia Court judges, health elements (doctors) and Wilayatul Hisbah. Details

16 Interview with the Head of General Crime Assistant of Meulaboh Prosecutor's Office, March 20, 2018. 
about the implementation can be seen in Articles 252 through Article 256 of Aceh Qanun Number 7 of 2013 concerning Jinayah Procedural Law.

Article 256 paragraph (4) states that if one element is not present, then whipping cannot be carried out. The execution of the sentence in Meulaboh was centered at Mesjid Agung Melaboh, which was chosen for security reasons. The convict was transported by the Prosecutor's Office to the execution location according to the area of the offense or the place where the misconduct occurred. The venue is selected at the expense of the relevant law enforcement officers and security guarantees from the local police so that unexpected events do not occur as a result of the community's reaction to the implementation of the whipping. As we know the execution of whipping involves several parties such as medical teams, religious leaders and local government officials. For this reason, the ceremonial operation of the whipping punishment requires costs and infrastructure, considering budgetary control imposed by the local regional government managed under the Civil Service Police Unit and Wilayatul Hisbah (WH) who prepare all facilities and infrastructure. These parties also execute whipping, while the Prosecutor's Office presents the convict and facilitator at the execution location and ensures various administrative completeness in the process of whipping. In this case, the supervising judge and observer were also present to oversee and evaluate the execution of the whipping sentence.

The results of research and observation in the Greater Aceh jurisdiction revealed that an execution was not carried out due to the defendant's pregnancy, causing her to be held in a Detention Center (Rutan) for three months.After giving birth, however, the defendant escaped and remained unknown. In this case, the execution of the sentence cannot be carried out, reflecting poor coordination between the Prosecutor's Office as the executor and the prison officer.

The execution of whipping is a sub-system of the Jinayah justice system. Therefore, in law enforcement, a system is required to run systematically between sub-systems for each of its stages. Likewise, the criminal justice system requires that every institution involved in the justice system work systemically. The realization of a systematic judicial process in the judicial process requires reliable coordination between law enforcement agencies themselves to uphold effective legal norms that are right on target. 
In addition to the aforementioned issues, there are also obstacles in the form of miscalculating the whipping counts that occur in the jurisdiction of the Jantho District Attorney. Until now, the excess number of whipping sentences has no legal instrument as a means of resolution, because the incident violates the principle of legality and the value of justice. Justice must be understood when the enforcement and application of the law are carried out in accordance with applicable legal rules. Moreover, the implementation of the criminal justice system must be oriented to ensuring that an act fulfills the criminal element, where the culprit and what criminal threats inflicted on him are known, as a legal consequence of a criminal act that has been proven through a proof system that includes evidence and evidence legal based on statutory regulations.

Different issues occur in the Aceh Pidie jurisdiction, where there are 48 jinayat cases from 2015 to December 2017, including maisir and khalwat, that are handled by the judicial process based on the applicable legal rules, both materially and formally. As in West Aceh, Aceh Pidie also faces budgeting obstacles for implementing the execution of the whipping punishment. National budgeting is different every year, sometimes the provision of costs for each execution schedule is not counted for how many cases, there is also allocated for each case that was executed even though it was done on the same day, but the Prosecutor's Office still tried to execute the whipping sentence which is still running despite the lack of available funds.

It should also be illustrated that in the jurisdiction of the Shari' ah Court of Pidie, the Pidie District Attorney has carried out the execution of whipping in the courtyard of the Office of the Public Prosecutor's Office. This reflects the seriousness of the Prosecutor's Office in upholding legal norms. Philosophically the whipping punishment carried out in public (public) in the Shari'ah law is oriented to the emergence of shame towards people who are subjected to whipping and causes a deterrent effect as well as the purpose of retaliation for the violations of the victim's rights. In addition, there have been attempts made by traditional leaders to advocate marriage as one of the solutions to the jinayat deeds in the form of khalwat and ihtilat. However, the settlement proposed by the traditional leaders did not prevent the Prosecutor's Office from continuing with the whipping execution.

The above situations of lack of funding are indicators that the effective implementation of whipping has not yet been met. In addition 
to the funding issues mentioned above, there are other issues that are also a concern, which mostly related to the development of human resources of law enforcement officials. The power and authority granted by legislation are not to create egocentricity between sectors but rather to bring cohesiveness in effective and efficient law enforcement. Furthermore, indicators of community development and education are also important because violations of legal norms are influenced by the level of community education, especially education and moral and religious guidance.

\section{Efforts made in overcoming barriers to the implementation of whipping.}

Whipping as one type of criminal in the jinayah qanun must be applied even though it raises protests considering its painful physical consequences. According to P.A.F. Lamintang, as quoted by Suhariyono, this type of punishment really hurts ${ }^{17}$ : Basically, the sentence was intended as misery for the perpetrators of criminal acts for their mistakes. The existence of such misery in the form of criminal law has resulted in criminal law gaining a separate place among other laws, which in the opinion of scholars, is seen as ultimum remedium or as a last resort that must be used to improve human behavior ${ }^{18}$.

The pros and cons of whipping in Aceh are not only because of the type of sentence but also against legal subjects and whether it can be imposed on non-Muslims. To non-Muslims, the execution of whipping has also been carried out, for example to Remita Sinaga or Mak Ucok, the residents of Central Aceh District on Tuesday, April 12, $2016^{19}$. The execution of the whipping sentence has caused a reaction from the local community. Many believe that non-Muslims should not be subject to this punishment, and ask the central government to

17 Suhariyono, Op.cit, 20-21.

18 Sholehuddin, Sistem Sanksi Dalam Hukum Pidana, Ide Dasar Double Track System \& Implementasinya, (Jakarta: Raja Grafindo Persada, 2003), hal. 45.

19 Farid Assifa, "Menjual Miras, Wanita Berusia 60 Tahun Dihukum Cambuk 28 Kali," KOMPAS, accessed May 1, 2017, https://regional.kompas.com/read/2016/04/12/13280461/Menjual.Miras. Wanita.Berusia.60.Tahun.Dihukum.Cambuk.28. 
reprimand Aceh, as appeared on a headline: "Whip Non-Muslim Women, the Central Government Asked to Reprimand Aceh". ${ }^{20}$

Law enforcement is a social sub-system, so it is truly influenced by its very complex environment, such as political, economic, social, cultural, science and technology, education, and so on. Law enforcement must be based on the principles of the rule of law as implied in the 1945 Constitution and the principles of law applicable in the environment of civilized nations (such as the Basic Principles of Independence of Judiciary) so that law enforcement can avoid negative practices due to the influence of a very complex environment. ${ }^{21}$

Based on the theory of legal effectiveness proposed by Soejono Soekamto, ${ }^{22}$ the effectiveness of a law is determined by 5 (five) factors:

1. The legal factor itself (the law).

2. Law enforcement factors, namely the parties who form or apply the law.

3. The factor of facilities or facilities that support law enforcement.

4. Community factors, namely the environment in which the law applies or is applied.

5. Cultural factors, namely the work, creation, and taste based on the human initiative in the association of life.

Furthermore, Romli Atmasasmita said the factors which hindered the effectiveness of law enforcement not only lay in the mental attitude of law enforcement officials (judges, prosecutors, police, and legal counsel) but also in the socialization of law that is often ignored ${ }^{23}$. In line with this, in their research, Din et al., suggest that the customary

20 Rafki Hidayat, "Cambuk perempuan non-Muslim, pusat diminta tegur Aceh,”.BBC Indonesia, accessed 15 April, 2016, https://www.bbc.com/indonesia/berita_indonesia/2016/04/160414_indon esia_aceh_qanun_hakim.

21 Muladi, Human Rights, Politics and the Criminal Justice System, Second Matter (Semarang: Diponegoro University Publisher Agency, 2002), 69.

22 Soejono Soekamto, Factors influencing law enforcement (Jakarta: PT. Raja Grafindo Persada, 2008), 8.

23 Romli Atmasasmita, Law Reform on Human Rights and Law Enforcement, (Bandung: Mandarmaju, 2001), 55. 
justice system in Aceh cannot be implemented as stipulated in the Memory of Undestending (MoU) because not all components of the community understand the contents of the $\mathrm{MoU}$ as a result of limited socialization. For this reason, it can be said that the low level of socialization is a factor obstacle in law enforcement. ${ }^{24}$

Law enforcement, justice, and human rights are the three keywords and a rule of law (rechtsstaat) theory. Justice is the essence of law; thus, a country must uphold justice if it refers to itself as a rule of law. Even the parameter for a country based on a system of law, but it is not guarantee of the existence of good law enforcement, such as in the implementation of whipping.

Specifically, for Aceh, the criminal justice system is implemented through the jinayah justice system, within which the Wilayatul Hisbah (WH) is controlled. Recognized since the time of the Prophet Muhammad, the Hisbah tradition has been practiced by the Apostles and followed by friends. "Hisbah traditions were put directly by the Prophet, who was the first Muhtasib in Islam. At this time, he entered the Medina market to oversee the buying and selling activities. The Prophet also delegated the task to friends (Khulafaurrasyidin), so that the delegation became the forerunner of the birth of the Wilayatul Hisbah. The existence of this institutions in the enforcement of Islamic law, one of which is by enforcing the jinayah qanun, in addition to the new authority within the judiciary, the Syar'iyah Court.

In many regions, syar'iyah court is normally a religious court environment, which authorizes restricted matters related to Nikah, Talaq and Ruju'. In Aceh, however, its authority is broader because it includes adjudicating jinayah cases. The execution of whipping, in particular, is carried out by the WH. Being a new institution, it still faces many imperfections in the sentence implementation. The obstacles faced in the implementation of whipping as mentioned above

24 Mohd Din, "The Implementation of the Implementation of Customary Courts by Investigators in accordance with the Joint Decree of the Governor of Aceh, the Aceh Regional Police Chief and Chairman of the Aceh Traditional Council No: 189/677/2011 / No: 1054 / Maa / Xii / 2011 / No: B / 121 / I / 2012" Research Report on Collaboration between the Faculty of Law at Syiah Kuala University and the National Police Commission, Faculty of Law, Syiah Kuala University, Banda Aceh (2014): 35 . 
have been attempted to be overcome by the executor, in this case the Public Prosecutor.

The Head of the Public Prosecutor's Office in Pidum Bireuen, during his serving period as the Sigli District Attorney, carried out a whip in the backyard of the prosecutor's office and witnessed by several people. He argues that this kind of action is better than waiting longer for the funds to be allocated ${ }^{25}$. This also does not contradict with the provisions in a way that even though it was not carried out in the courtyard of a mosque, it was witnessed by the public and attended by the required personnel. Incidentally, the number of whips applied was also low and considered as a form of education.

The executor in the execution of whipping is more filled with enthusiasm. In this particular case, it is not just the enforcement of the provisions of the legislation but is also filled with the spirit of law enforcement by looking at better goals. Kasi Pidum Sigli said that the efforts made to overcome the constraints of lack of funds were with the whip makeshift funds carried out. If there is a high number of convictions, the execution of whipping will be carried out immediately with the available funds.

As the funds were expected from the local government, the executor (prosecutor) approached the regional government to overcome any financial constraints. As presented earlier, the Prosecutor's Office in Meulaboh approached the Local Government so that some of the suspended executions that had been piling up from 2015 were finally implemented in 2017. Likewise, in the instances where the whip convict could not be presented, the Prosecutor's Office also tried to find and summon the convicted persons.

Concerning the summoning of the convicts, the cases cannot be generalized. In this context, some of the convicts attempted to avoid the sentence, while some others voluntarily attended the execution without any element of coercion ${ }^{26}$. This means that they come with the full awareness that punishment is something that must be respected. In the jurisdiction of the Jantho District, various obstacles have been tried

25 Interview with Head of General Crime of Bireuen District Prosecutor's Office on 7 August 2018.

26 Explanation from the Head of Pidum of the Meulaboh District Prosecutor's Office March 20, 2018. 
to be overcome by the spirit of law enforcement. For example, when a convict who suffers from diabetes is recommended not to take the whipping sentence, the prosecutor's office took the initiative to reconsider his sentence.

To overcome obstacles to the lack of coordination between law enforcement in the judiciary in general and the execution of whipping in particular. The parties continue to coordinate and in the course of the equality of perception and coordination increasingly leads to better.

\section{CONCLUSION}

One of the obstacles that caused hindrances to the implementation of whipping punishment were mainly the problem of funding, human resources and stakeholder coordination. The execution of whipping requires funds and involves different agencies, namely the Prosecutor's Office as the side in charge of the execution, health workers, judges, and shariah police (the Wilayatul Hisbah). The lack of coordination between the such subsystems in the jinayah justice has contributed to different level of effectiveness of the punishment. Efforts made by the prosecutor's office to overcome funding are to carry out executions with improvised funds and seek to coordinate with the local governments. Related to the delay of whipping due to the difficulty of bringing the perpetrator, the prosecutors should coordinate with community leaders along with raising awareness and understanding to the community, particularly on the essence of this punishment to relief the perpetrator from a sinful burden in hereafter. It is an underlying reason, where some of the convicts attended the execution voluntarily, without any coercion.

According to this, the seriousness of the government needed, especially the Aceh government to prepare the necessary facilities, especially funding, as well as in the need for good coordination between law enforcement agencies and local governments for better enforcement of shari'a law in Aceh province, Indonesia. Such a good picture can react to other parts of Indonesia which also sympathy to the comprehensive (kaffah) application of Syariah Law. 